\title{
Cover crops for improving crop and soil management
}

\section{Editorial}

Increasing agricultural production is generally a desirable goal in the context of an increasing World human population. The intensification of agricultural practice during the second half of the XX century, with more inputs (such as fertilizers, pesticides, irrigation) allowed significant yield improvement in most arable crops. However, at the same time, these types of farming systems, together with other human activities, have contributed to many negative environmental impacts leading to several risks or damages: greenhouse gas emissions, a consumption of fossil energy, the high use of pesticides and the use of increasing amounts of water for irrigation which contributes to the depletion of underground water. Arable crops are responsible for half of the world $\mathrm{N}_{2 \mathrm{O}}$ emissions issued from human activities. Industrial nitrogen fertilisers are usually the major source (70 to $90 \%$ ) of $\mathrm{N}_{2} \mathrm{O}$ emission linked to an agricultural product. A consumption of fossil energy, contributing to resource scarcity and this is also mainly linked to the use of more nitrogen fertilizers which represents more than $50 \%$ of the energy consumption in the farm systems based on arable crops. The increasing use of chemical fertilizers has affected the nitrogen (N) cycle, resulting in a dramatic elevation of the amount of reactive nitrogen in the biosphere, which has negative consequences on climate, ecosystem resilience and health. The high use of pesticides, leading to contamination of water, air and soils with risks of toxicity.

The use of cover crops is one measure that has been taken in agricultural production in order to increase environmental protection and to encourage sustainable use of natural resources. Cover crops are using to design new strategy that preserves farm natural resources while remaining profitable. The practice of cover cropping in some regions has gained importance in view of the decline of animal production and the related reduced availability of organic fertilizers. In some cases such as the Vojvodina province, Serbia, fertile soils like chernozem have suffered a significant reduction in humus content, in some cases as much as $50 \%$, which justifies the introduction of cover cropping in commercial production. The integration of cover crops into cropping systems brings costs and benefits, both internal and external to the farm. In annual cropping systems, cover crops are often included to maximize benefits such as biomass and nitrogen production. Cover crops can increase yields and at the same time, they can reduce costs, increase profits and even create new sources of income. Some studies showed that cover crops become more profitable as the price of nitrogen increases. Biological $\mathrm{N}$ fixation by legume cover crop can act as a sustainable source of $\mathrm{N}$ and can complement or replace some fertilizer inputs.

Many cover crops offer harvest possibilities as forage, grazing or seed that work well in systems with multiple crop enterprises and livestock. Cover crops could be used also as green manures that are grown and tilled under to add nutrients and improve the soil. Smother crops are used to control weeds. Living mulches are planted around or beside cash crops for weed control.

Cover crops offer many benefits to sustainable agriculture such as: cut fertilizer costs, reduce the need for herbicides and other pesticides,
Volume I Issue 2 - 2014

\author{
Branko Cupina \\ Faculty of Agriculture, University of Novi Sad, Serbia
}

Correspondence: Branko Cupina, Department of Agriculture, University of Novi Sad,Trg D. Obradovica 8, 21000 Novi Sad, Serbia,Tel +38I-2 I-485-3457, Email nauka@polj.uns.ac.rs

Received: June 20, 2014 | Published: June 21, 2014

improve yields by enhancing soil health, prevent soil erosion, conserve soil moisture and protect water quality. By reducing reliance on agrichemicals for cash crop production, cover crops help protect the health of people. They also help address community health and ecological concerns arising from nonpoint source pollution attributed to farming activities. Benefits vary by location and season, but at least two or three occur with any cover crop.

Species from the family of legumes (Fabaceae), grasses (Poaceae) and crucifers (Brasicaceae) are commonly used as cover crops. For ecological reasons, legumes are gaining increasing importance since nitrogen use in arable lands is the cause of several major environmental problems, and since additional nitrogen is needed by all arable crops, except legumes. Legume cover crops can be easily included in a crop rotation and in contrast to grasses and crucifers, contribute additional $\mathrm{N}$ to the nutrient cycle by symbiosis. Most of the symbiotic $\mathrm{N}$ is used for legume growth and is therefore accumulated in organic matter. Some of this $\mathrm{N}$ can be used later as animal feed in the form of protein in herbage while the rest of the accumulated $\mathrm{N}$ can be taken up by subsequent crops after ploughing-in and mineralisation of the organic matter. Legume-cereal mixtures show great potential over a wide range of niches. Bi-culture legume-cereal cover cropping may enhance above and below ground biomass yield and $\mathrm{C}$ and $\mathrm{N}$ content. The increase in $\mathrm{C}$ and $\mathrm{N}$ supply to the soil has the potential to improve soil quality and crop productivity compared with monoculture cover crop species. Cropping systems that include legume cover crops provide symbiotically fixed nitrogen and potentially increase yield through improved resource use efficiency in time and space. Most of studies dealing with legume-based cropping concern a legume grown with a non $\mathrm{N}$ fixing species. Fast-growing cover crops such grasses and crucifers hold soil in place, reduce crusting and protect against erosion due to wind and rain. They can be grown whenever the soil is left bare for part of a season. After harvest, more cover crops can be planted and provide cover throughout the winter.

\section{Acknowledgements}

None.

\section{Conflict of interest}

The author declares no conflict of interest. 